\title{
Forum
}

\section{Response to Wolfgang Hirczy}

Thanks to Wolfgang Hirczy ("STV and the Representation of Women," PS December 1995, 71113) for raising interesting questions.

First, he asks why Malta was not included with my presentation in $P S$ of women's representation in parliaments in long-established democracies ("Women's Underrepresentation and Electoral Systems," PS, December 1994, 689-92.

Malta was omitted for it did not meet the criteria for a long-standing democracy when I carefully classified 113 countries for 1987-91. Malta was classified as a partially developed democracy for, among other things, it did not meet the criteria for free and fair preelection conditions.

The 27 partially developed democracies that I classified-including Malta-generally have low proportions of women parliamentarians (mean $=6.5 \%$ ) regardless of electoral systems. The exceptions are countries that have large multiseat districts (seven or more representatives in a district) or have positive procedures for including women, such as a proportion of seats reserved for women. (See "Parliaments Of, By and For the People: Except for Women?"' in Electoral Systems in Comparative Perspec- tive: Their Impact on Women and Minorities, edited by Rule and Joseph P. Zimmerman, Westport, CT: Greenwood, 1994, pp. 22-24).

Malta's low women's representation also appears related to lack of political party support for more women parliamentarians, a state religion, few women college graduates and women working for pay which, in turn, is a factor for a narrowly based women's movement to promote women's equity. All these factors retard women's political representation according to numerous statistical and other studies.

Second, he questions why three countries with the same electoral system-namely the single transferable vote form of proportional representation-vary in their legislative representation of womenMalta (2\%), Ireland (12\%), and Australia (Senate, 24\%).

Democratic Ireland's low representation for a proportional representation country is likely to be due in part to the preponderance of small districts (four representatives or less in a district), high (80\%) incumbency, and other factors. Small districts are typically unfavorable for women candidates. (See Richard L. Engstrom, "District Magnitude and the Election of Women to the Irish Dial," Electoral Studies 6(2), 1987, 123-32). Incidentally,
Ireland has a strong women's movement, which actively promoted the successful referendum vote for divorce in 1995.

As for the higher proportion of women (24\%) in Australia's senate, this may be explained in part by large statewide districts electing 12 senators each. Also significant is the check-off for a party's order of candidates, rather than the voters ranking individuals using the single transferable vote form of proportional representation. Thus Australia's senate election system behaves somewhat like the open party-list system of proportional representation which has resulted in women's representation of up to $40 \%$ in northern European democracies.

The major conclusion I derive from this is that an electoral system which should be generally favorable to women-namely proportional representation-is a democratic tool that can be blunted by undemocratic procedures, small districts, incumbency, political party indifference, etc. This toolderived from philosophic notions of inclusiveness, fair representation and governmental legitimacy-can also be honed to bring women closer to representational equality.

Wilma Rule

University of Nevada, Reno 